\title{
Inglid ja Inglipesa internetifoorum uue vaimsuse kandjate ja legitimeerijatena
}

\begin{abstract}
Marko Uibu
Teesid: Artiklis analüüsitav Inglipesa foorum näitlikustab tänapäevaste inglikujutelmade rolli uue vaimsuse keskkonnas. Sümbolite või ka tegelikkuses eksisteerivatena tajutud abiliste-juhendajatena suudavad inglid kanda vajalikke tähendusi; nende toel täidab Inglipesa olulisi funktsioone - pakub raskel hetkel tuge, võimaldab tunda seotust ja heasoovlikkust, loob ja kinnitab argiusundis tähenduslikku. Inglid on foorumis kujunenud uusvaimsuse kesksete väärtuste (individualistlik eneseareng; holistiline ja hooliv suhtumine maailma ja inimesse) ning maailmaga suhestumise viiside (subjektivismi või seostav teadmine) kandmisel ja nende legitimeerimisel oluliseks sümboliks ja toeks. Inglipesa kui aktiivne virtuaalne keskkond võimaldab vaadelda veebisuhtlusel põhineva tugirühma toimimist ning vaimsete ja religioossete tähenduste loomist.
\end{abstract}

Märksõnad: inglid, online-etnograafia, religioosne sünkretism, uus vaimsus, virtuaalne kogukond

\section{Sissejuhatus: inglid ja Inglipesa internetifoorum}

Inglikujutelmade jõuline tagasitulek inimeste uskumustesüsteemi, mis Ameerikas algas 1990. aastatel (Gardella 2007), jõudis Eestisse mõnevõrra hiljem. Veel 2004. aastal kirjutas professor Anne Kull Usuteaduslikus Ajakirjas: "Üldjuhul meie maailmapildis inglitele kohta pole. Kui üldse, siis kuuluvad inglid punnpõsksete tiibadega lapsukestena jõuludekoratsioonide hulka" (Kull 2004: 112). Teoloogilisest perspektiivist ning eriti Eesti kontekstis võiski tunduda loogiline, et inglitaoliste kristlike sümbolite suutlikkus kõnetada laiemaid rahvahulki on jäänud minevikku - et inglid on muutunud tühjadeks sümboliteks postkaartidel või pildiraamatutes.

2011. aastal Saar Polli poolt läbi viidud uuringus osutusid inglid eestlaste seas aga üllatavalt populaarseks. Täiesti või pigem nõus, et "on olemas inglid, kes aitavad ja kaitsevad meid", oli 48,2 protsenti küsitlusele vastajatest (Jõks 2012: 296). ${ }^{1}$ Võrdluseks: isikulise jumala olemasolu väitis end uskuvat ligi $20 \%$ 
vähem inimesi ning paradiisi (taeva) olemasolu suisa kaks korda vähem inimesi - kõigest 24,4\% küsitletutest (Jõks 2012). Seega ei nähta ingleid tihti enam jumala abilistena - inglid on kolinud taevast alla maa peale, inimeste juurde.

Ehkki küsitlusele vastanute seas leidub kindlasti ka neid, kelle usk inglitesse pärineb kristlusest, on põhiliseks inglite populariseerijaks muutunud uue vaimsuse õpetused ning popkultuur: inglid figureerivad näiteks reklaamides (Hiiemäe 2012) või mitmetes vaimse arengu ja tervendamispraktikates (Utriainen 2014). Inglite taaselustumine uue vaimsuse keskkonnas illustreerib religioossete tähenduste muutumise laiemat tendentsi. Uue vaimsuse pakutav sobitub tänapäeva inimeste maailmapilti paremini kui näiteks rangelt Piiblist lähtuvad käsitlused. Maailma keskmesse on nihkunud inimene ning õpetused, mis sellega ei arvesta, heidetakse lihtsalt kõrvale (vt Pekko \& Koppeli (2013) analüüsi kristluse ja uue vaimsuse kokkupuudetest). Ebameeldivat ja ohustavat püütakse pigem ignoreerida: näiteks usuvad küsitlustele vastajad pigem taeva kui põrgu olemasolu. Samuti on teisenenud kristlike pühade tähendused. Jõulud on inimkonna patte lunastava Kristuse saabumise tähistamisest muutunud peresuhete väärtustamise rituaaliks, kus sugulased kogunevad kinkide ning pidusöögiga oma suhteid uuendama-kinnitama (vt Woodhead 2012).

Selliseid tendentse arvestades pole üllatav, et ka inglite tähendus on oluliselt muutunud. Inimesi pigem hirmutavatest jumala käskjalgadest ja kõigevägevama tahte elluviijatest on saanud inimeste kuulekad abilised (Utriainen 2014). Argiusundi sünkretistlikes mustrites on mitmetele kristlikele sümbolitele ja rituaalidele lisandunud uued kontekstid ja kasutusviisid, kombineerides neid popkultuuri ja muu inimesi kõnetavaga (Woodhead 2013). Ka Eestis on 2000. aastate teisest poolest täheldatav inglite suurem esindatus meediaruumis: mitmed vaimsusest huvitunud näitlejad-lauljad (nt Kleer Maibaum-Vihmar) on rääkinud ajakirjanduses inglite olulisusest; ilmunud on paljud populaarsed ingli-teemalised raamatud, sh ka eesti autoritelt (Hiiemäe 2012). Inglid on kristluse, uusvaimsuse ja popkultuuri ühendamisel osutunud üheks edukamaks sümboliks. ${ }^{2}$

Tendentsid, mis toovad inglid kristlikust kirikust pigem uusvaimsetesse praktikatesse, võivad tuleneda õpetustest, kuid ka traditsioonilise religiooni struktuursetest ja vormilistest eripäradest. Kirik ei ole senini olnud kuigi võimekas nüüdisaegsete kommunikatsioonikanalite rakendamisel ja inimestega sisuliste suhete dialoogilisemaks muutmisel (Waters \& Tindall 2010). See avaldub ilmekalt näiteks veebikeskkonnas, kus tekib üha rohkem kirikuga mitteseotud vaimseid-religioosseid lehekülgi. Veebifoorumeid iseloomustab dialoogilisus, tugeva hierarhia puudumine, mis sobitub tänapäeva inimese arusaamaga religioossest osalusest. Internet on kujunenud religiooniga seostuvate tähenduste 
loojaks ja kandjaks: näiteks on välja toodud, et virtuaalkeskkonnast otsib pidevalt teavet jumala kohta 28 miljonit ameeriklast (Waters \& Tindall 2010). Uusvaimsuse õpetajad ja järgijad võtavad internetti kui loomulikku keskkonda õpetuste virtuaalseks loomiseks, kogumiseks ja jagamiseks (Noomen \& Aupers \& Houtman 2011) ning ka inglitele või inglitega seotud tavadele on pühendatud palju veebilehekülgi.

Uue vaimsuse inglite populaarsuse põhjuste analüüsimisel on välja toodud, et see näitab religioossete institutsioonide rolli vähenemist ning viitab inimeste kaugenemisele organiseeritud religioonist (Draper \& Baker 2011). Ajalooliskultuurilise tausta tõttu toimub Eestis aga pigem vaimsuse ja inglite (taas) avastamine kui kristlikust kirikust eemaldumine. Inglid on olnud eesti kultuuriruumis traditsiooniliselt mõneti “tühjemad” sümbolid kui Läänes: inglite tähtsus ei ole luteri kirikus olnud märkimisväärne (Paul 2008), samuti kohtab ingleid võrreldes teiste mütoloogiliste olenditega vähem siinses folkloristlikus pärimuses (Valk 2007). "Vaimsel otsingul" inimeste kombineeritavates sünkreetilistes argiusundilistes mallides on inglid osutunud üllatavalt tähenduslikuks, ning nii, nagu eestlaste individuaalses religioossuses sageli, saavad ka siin kristluse asemel olulisemaks hoopis uue vaimsuse allikad ja põhitõed (vt Altnurme 2012). Keeruliselt piiritletava ja määratletava uue vaimsuse puhul võib kesksete printsiipidena välja tuua vaimse enesearengu müüdi, individuaalse arengu tähtsustamise, mis kujundab nn mina-vaimsust (Altnurme 2013); samuti endale sobivate praktikate ning uskumuste tõeväärtuse hindamisel isikliku (või endaga sarnaste inimeste) kogemuse rõhutamist (Hammer 2010).

Vaatamata eestlaste näilisele usuleigusele on Eestis tegelikult erinevatele rahvausundilistele tõekspidamistele viljakas pinnas. Näiteks 2010. aasta uuringus nõustus 39 protsenti vastajatest väitega "teatud maagiliste toimingute või rituaalidega on võimalik mõjutada sündmuste käiku ja teisi inimesi"; 58 protsenti tunnistas aga, et "teatud märgid ja ended võivad elu pöördelisi sündmusi ennustada" (Altnurme 2013). Seega on eestlastele siiski omane nn maagiline mõtlemine, mis väljendub ka siinse uue vaimsuse keskkonna aktiivses toimimises või inglite-taoliste üleloomulike olendite populaarsuses.

Tänapäevaste inglite ning inglipraktikatega seonduv materjal on rikas ning võimaldab väga erinevate aspektide analüüsimist. Tuginedes eestikeelse veebilehe "Inglipesa. Valgustumise foorum" (http://pesa.valguseleht.ee/inglipesa/) aruteludele, vaatlen käesolevas artiklis inglikujutluste esilekerkimist uue vaimsuse keskkonnas, küsides, miks on inglid populaarsed, mida nad inimestele pakuvad ning miks see toimub just uue vaimsuse keskkonnas ja uue vaimsuse keelt kasutades. 


\section{Internetikeskkondade ning Inglipesa foorumi uurimisest}

Internetisuhtlus on muutunud sotsiaal- ja humanitaarteadlastele põnevaks uurimisobjektiks. Leidub väga erinevaid arvamusi etnograafilise uuringu võimalikkusest ja vajalikkusest veebikogukondades ja -keskkondades (vt nt Beaulieu 2004). Intrigeeriva ja potentsiaalselt paljupakkuva allikana on virtuaalkeskkondade etnograafiline uuring leidnud käsitlemist erinevate nimetuste all: online etnograafia (nt Markham 2005), interneti- või virtuaaletnograafia (Hine 2000); netnograafia (Kozinets 2010) või ka küberantropoloogia (Budka \& Kremser 2004). Wilson ja Peterson (2002) väidavad, et online ja offline kogukondade analüüs ei vaja kardinaalselt erinevaid lähenemisi, muutuvad lihtsalt rõhuasetused: näiteks tähtsustub keele roll.

Internet võimaldab ligipääsu kogukondadele ja inimeste omavahelisele suhtlusele ilma vahendajateta. Samas tuleb arvestada, et veebisuhtlus hõlmab vaid väikese osa inimeste igapäevasest elust ning rollid ja identiteedid on internetis tavaelust oluliselt paindlikumad ja mängulisemad (vt Suler 2007). Internetifoorumis toimuva suhestamine inimese igapäevaste praktikate ja eluga väljapool virtuaalkeskkondi on keeruline. Erinevaid sotsiaalseid rühmi iseloomustavad internetis erinevad kasutuspraktikad ja eesmärgid. Samuti on kontekstuaalselt oluline interneti üldisem kättesaadavus. Eestis on internetikasutajate seas alaesindatud küll teatud earühmad (nt vanemad pensioniealised), kuid internet on üldiselt rahvastiku valdavale osale kättesaadav. ${ }^{3}$

Internetikogukondades kujunevad välja erilised kommunikatiivsed tavad, mis loovad ja hoiavad virtuaalseid suhteid. Käesolev analüüs ei püüagi teha kõikehõlmavaid järeldusi inglite rolli või uue vaimsuse veebifoorumi tähenduse kohta. Uuring põhineb vaimse internetifoorumi "Inglipesa (Valgustumise foorum)" analüüsil ning vaatleb foorumit kui online-keskkonda, mis toetab uue vaimsuse ideedest kantud diskursiivse kogukonna toimimist.

Inglipesa lehekülg loodi novembris 2009. Praegusel ${ }^{4}$ hetkel on foorumil ligi 1450 registreeritud kasutajat ja sealt leiab 2700 teema alt üle 36300 postituse. Kokku on lehekülge vaadatud üle 5,4 miljoni korra. Foorumi asutaja ning administraator Kaledon (siin ja edaspidi on kasutajatele viidatud nende Inglipesa nimedega) kirjeldab Inglipesa algatamise motivaatorina missiooni luua "kõrgvibratsiooniline" koht, kus inimesed saaksid olla need, kes nad päriselt on. Tema sõnul ei tekitanud teised veebilehed temas "kangelasliku valguskandja tunnet", kuid Inglipesa kui "valgustumise foorumi" asutamine seondub Kaledonil ka isikliku valgustumisega. Ta näeb foorumiga tegelemises enda sügavat kutsumust, milles on tuntav tugev spirituaalne dimensioon. 
Teadsin, kes ma olen, mida ma usun ja kuidas mõtlen. [---] Et olen leidnud oma õige tee ja selle, kes ma sisimas olen, teen seda, mida on mulle määratud teha. Seda on raske kirjeldada. Varem polnud mul eriti tulevikutunnet, minevik oli liiga domineeriv, elasin peamiselt olevikus. Siis aga tundsin olevikku, tulevikku ja minevikku samaaegselt, see oli nagu lai väli minu ümber. Ja need kolm olid nagu üks, minu auraväli. ${ }^{5}$

Sellist missioonitunnet ja motivatsiooni leiab kahtlemata väga väheste veebikeskkondade moderaatoritel.

\section{Analüüs}

Foorumitekste analüüsides lähtun kahest kesksest küsimusest: mida pakub Inglipesa foorum kasutajatele ning kuidas ta seda teeb. Uurimisküsimustele vastamiseks olen 2012. aasta algusest jälginud foorumi diskussioone ja lugenud läbi suure osa varasematest postitustest, mille käigus olen teinud jooksvalt märkmeid. Märkmete põhjal ilmnesid korduvad teemad ja mustrid, mille illustreerimiseks toon artiklis foorumist pärinevaid tekstinäiteid. Et tabada foorumi laiemat konteksti, suhtlesin internetis ning kohtusin mitme aktiivse foorumiliikmega.

\section{Tähenduste loomine}

Inglipesa pakub mugavat ja turvalist keskkonda, kus oma ideid katsetada ja tundmustele-kogemustele tagasisidet saada. Seetõttu toimib lehekülg argiusundiliste tähenduste inkubaatorina, kus kasutajad leiavad kinnitust oma kogemuste-tajude-emotsioonide tähenduslikkuse kohta. Näiteks 24aastane Elessandra registreeris end Inglipesa kasutajaks just erilise elamuse tõttu, millele ta palus kogenenumate inimeste kommentaare.

oli ilus sügisõhtu, kui oli juba parajalt hämar õues ja taevas oli mõnusalt kirju loojuvapäikese kiirtest. Tegin akna lahti ja siis tegin nutitelefoniga pilte. [---] pildistasin ja vaatasin, et mida, nagu lilla linnuke või väike inglike on pildil. Sattusin nii elevusse et kiirustasin kõigile rääkima. Ja nii end lolliks tegin, kõik naersid minu üle. [---] Siis avastasin täna veel et kui hakkan telefoniga pildistama ja tekib välk, siis nagu mistki hele ja erk valge täpike tiirutab fookuses. See on ilus ja armas aga tekitab ärevust kuidagi. [---] Kas tegemist võiks olla kaitseingliga? Ma pole nagu usklik ega midagi sellist, paranormaalsusi mingil määral usun. 
"Enda lolliks tegemisest" häiritud Elessandra leiab Inglipesas tuge, sest seal hinnatakse fotosid väga kõrgelt. Näiteks Gardamea, foorumi suurliige, selgitab, et Elessandra suudab tavainimestest lihtsalt rohkem näha:

Meie ümber olev maailm on palju rikkam, kui me seda endale ette oskame kujutada. Inglid kui ka muud vaimolendid on kõrgema vibratsiooniga, seetõttu inimene, kes on argipäeva muredes ja negatiivsetes mõttemustrites kinni, neid ei tunneta-näe. Aga see ei tähenda, et neid olemas ei ole.

Elessandra postitab seepeale veel pilte ning on kommentaaridest vaimustunud: "Gardemea kui sinu postitust lugesin jooksid judinad üle kohe:)".

Daniele Hervieu-Leger (2001) rõhutab, et nõrga institutsionaalse või rühma toe tõttu jääb vaimses keskkonnas uskumuste ja teadmiste kinnitamine sageli suures osas indiviidi enda kanda. Kinnituse leidmine on aga protsess, mis vajab välist tuge. Näiteks kirjeldab Tanya Luhrmann (2012) mehhanisme, kuidas evangeelsed kristlased leiavad kindluse jumala olemasolus ning õpivad tundma jumala häält. Erinevalt Luhrmanni analüüsitud USA kirikutest, kus protsess on tugevalt juhendatud (regulaarsed kogunemised, kirikuõpetaja loengud ja abi, koguduseliikmete (palve)rühmad, kirjalikud materjalid), leidub uue vaimsuse keskkonnas tugipunkte vähem. Lisaks raamatutele ja meediale on informatsiooni leidmiseks ja oma kogemuste tähenduse kinnitamiseks üha olulisem internet, mida näitavad ka Inglifoorumi diskussioonid.

Inglipesas arutletakse nii vaimsuse või üleloomulike nähtustega seotud kui ka maistel ja igapäevaelulistel teemadel. Sarnaselt paljudele populaarsetele eestikeelsetele foorumitele (nagu perekool.ee) võimaldab Inglipesa nõu küsida või juba olemasolevatest postitustest vajalikku-huvitavat infot otsida. Järgnevalt vaatlen täpsemalt arutelusid, mis keskenduvad foorumis inglitega seotud põhiküsimustele: kas ja kuidas ingleid näha; kuidas tunda ära ja tõlgendada inglite saadetud märke ja endeid.

Sellesisuline küsimus kasutaja Teresalt ("kuidas te ikkagi näete... ingleid, haldjaid?") kogub väga erinevaid vastuseid. Mitmed foorumi liikmed kirjeldavad reaalselt ingli nägemist - ingel on kui "valguskiire sees õrn helevalge, pea läbipaistev haldjas" või lihtsalt “õrnvalge kogu”. Üks kasutaja vastab, et tema "konkreetselt kedagi ei näe, nagu näen tavalisi asiu. Ei ole nii, et vaatan enda kõrvale ja reaalselt naeratab Ingel mulle vastu $($." Inglid tähistavad tema puhul "pigem kellegi kohalolu ja soojust, energeetilised tundmused on ka". Teresa haakub samuti pigem sellise arusaamaga ning mõtiskleb sealt edasi ka oma kogemuste-tundmuste üle:

...see kellegi kohalolek ja soojus, energeetilised tundmused - ongi ehk seesama iseenese heaolu tunne, noh, et on lihtsalt väga-väga hea olla, oled mõttes hästi tänulik ja täis armastust ja tunnetad iga keharakuga seda 
kõike - sellist suurt soojust olen ise ka tunnetanud/tundnud, kus süda on äärast ääreni otsatut headust, tänulikkust täis, teisiti nimetatakse seda:pisarateni liigutatud - See tuleb meist endist, meie hingest - tähendab, see(Hing) ongi Ingel või Haldjas? :)

See arutelu viitab, et võrreldes näiteks kristliku Pereraadio vox populi tüüpi saatesse helistanud ja oma inglikogemustest rääkinud eestlastega (vt analüüsi Potter 2001), ei tule Inglipesas välja sedavõrd kindla struktuuriga kogemuslood ehk memoraadid. Inglid ei võta kaitsja või hoiataja rolli ohtlikes situatsioonides, nagu tõi välja Potter (2001), pigem pakuvad nad lohutust raskes olukorras. ${ }^{6}$ Inglite konkreetsemal kujutlemisel on kasutajatel suhteliselt suur vabadus ja käsitluste erinevusi tolereeritakse. Foorumi aktiivsemate liikmete väitel eksisteerivad inglid üldiselt ka reaalselt, ehkki neid nähakse erinevalt: valdavalt (positiivse) energiakogumina, mida on võimalik tajuda, kuid leidub ka neid, kes näevad ingleid füüsilisel kujul. Inglid võivad olla ka sümboolsed kujundid, mis koondavad positiivsust (sinna liigub Teresa käsitlus). Kõige abstraktsemal tasandil on inglid lihtsalt keel, formularid, kuidas midagi öelda, millessegi suhtuda (selliseid viise inglite kirjeldamisel toob välja Walter 2011: 47). Samas kaasneb inglitega teatud kompleks defineerivaid väärtusi (headus, soojus, sõbralikkus), mille põhjal inglit on üleüldse võimalik ära tunda. Seega eksisteerivad siiski tunnused, millele "õige" inglikogemus peab vastama.

Inglite otsesest tajumisest enam püüavad Inglipesa kasutajad tabada inglite saadetud märke. Enimlevinud märkidest võib välja tuua sümbolina valge sule. Paljudes lugudes kordub motiiv sule nägemisest või leidmisest tähenduslikel või ingli(te)ga seonduval hetkel. Suled on ka üldisemalt inglite kohalolu kinnitajaks. Nagu kirjeldab kasutaja Muusa:

Mina leian alailma valgeid sulgi kõikvõimalikest kohtadest, mu 1. teadlik inglisulg on mul siiani kaasas teatud kohas. Usun, et see toob mulle ka onne.

Sulgede või muude väikeste esemete hoidmine talismanina on üsna levinud. Ka kasutaja Miracle kirjutab, kuidas ta hoiab lasteaias oma lapse juustest leitud valget sulge siiani lapse voodi juures. Oma postituses viitab ta ka võimalikule mittemõistmisele inimeste poolt, kes ingliusku ei jaga: ehkki Miracle tahtis sule leidmisel rõõmust hõisata, püüdis ta end enda sõnul siiski tagasi hoida, et kasvatajad ei "vaataks teda kui hullu".

Foorumist leiab palju enda igapäevaeluliste olukordade tõlgendamist lähtuvalt inglite mõjust, mida muidu justkui ei olegi märgatud, kuid nüüd Inglipesas oma kogemuste üle mõtiskledes saab see selgeks. Inglite heatahtlikkus avaldub kasvõi väikestes märkides, mis aitavad igapäevaelulistes olukordades jõuda (sageli ootamatultki) hea tulemuseni. Märke püütakse ära tunda ning leida 
lisakinnitusi, et tegemist on tõepoolest just ingli sekkumisega. See õnnestub näiteks järgnevas loos:

Nädal tagasi juhtus minu jaoks imeline asi. Pidin minema ühte kohta. Sinna minnes pidin mööduma ühest poest. Enne poodi märkasin oma imestuseks ühte armsat liblikat lendlemas.Mõtlesin veel,et uskumatu et niisuguse jaheda ilmaga liblikad ikka veel lendavad. Jälgisin tema lendlemist... ja tabasin ennast mõttelt, et äkki on tegemist märguandega. Liblikas muudkui lendles ja lendles...poe suunas. Pidasin endaga hetkeks nõu ja otsustasin poodi minna. Jalutasin siis seal riiulite vahel ja siis ühel hetkel mõtlesin,et läheks kaeks jalanõude osakonda. Leidsin endale sealt super mugavad ja kõvasti allahinnatud suvekingad järgmiseks suveks. Kusjuures mul on alati olnud väga raske leida häid jalanõusid ja need on just niisugused nagu vaja ja peab. Oi ma olen väga happy nende kingade pärast! :-) Igatahes sain aru,et olen elanud siiani nagu pime. Kindlasti olen saanud ka varem inglitelt märguandeid aga ma lihtsalt pole osanud neid märgata. Selle märkamise tarkuse sain siit portaalist. :-)

Selline "märkamise tarkus" viitab otseselt teatud viisidele, kuidas ümbritsevat tõlgendada. Nagu eelneva näite puhul, ei ole paljude märkide puhul seos inglitega väliselt kuigi iseenesestmõistetav. Kasutaja Mereliilia kirjeldab oma kogemust:

Hetk tagasi maadlesin ühe probleemiga ja palusin vastust Inglitelt. Sain selle pesumasinast, kui leidsin 20ne sendise Kõik tundub ikka veel nii uskumatu olema! Mina, kes ma arvasin, et ma ilmselt ei saa saamagi sõnumeid neilt Imelistelt olevustelt, pean tunnistama, et eksisin

Iseloomulikult foorumi tonaalsusele ei sea teised kasutajad Mereliilia tõlgendust kahtluse alla, vaid väljendavad selle üle rõõmu. Kasutaja Naida vastab: "Imeline uudis;D Inglikallid ja loodan, et märkad, saad neid s6numeid edaspidi veelgi enam."

Inglite ja nende saadetud märkide tuvastamiseks ei rõhutata üldiselt väliste ja objektiivsete standardite olulisust, vaid pigem sisetunnet. On iseloomulik, et näiliselt tavaline ja üldse mitte üleloomulik kogemus võib saada erilise tähenduse kui inglitega seotu, kui kogetakse õnnetunnet või erilist headust. Kasutaja Melodia selgitab seda enda näite varal:

Inglitelt märgid on imelised ja neist jääb hinge armastust täis tunne. Nt selline, et korrastasin ükspäev sugulaste nõudekappi. Pesin ja sättisin. Ja siis järsku ilmusid nõude vahelt imelised kuldsed tiivad. Kindlasti mingi jõulukaunistuse küljest. Kuid kui ma neid vaatasin siis valdas mind 
imeline armastust täis tunne, kus oli ka tunda kiitust ja tänu. Tunne oli $k a$ selline nagu inglid ütleksid tubli oled ja teeksid pai.

Ehkki Melodia seostas ka ise kuldsed tiivad kohe jõulukaunistusega, mis tema hinnangul ei ole midagi erilist või üleloomulikku, tõendab märgi ingellikust just "imeline armastust täis tunne". Ka paljude teiste kasutajate kirjeldustes on inglite ilmumine või nende märgid tuvastatavad teatud kindlate parameetrite abil nagu hea enesetunne, soojus, valgus, mis võib isegi tavalisi kogemusi väga eriliseks muuta. Selline teadmine suunab inimesi märke erilisena tõlgendama ning seeläbi võimaldab külma, "kainenenud" (Max Weberi kuulus tees kaasaegse maailma "lummusest vabanemisest" ehk disenchantment'ist) ja müstikavaest maailma näha põneva, mõtestatu ning inglite puhul lisaks ka läbinisti heatahtlikuna.

Foorumi üldine tonaalsus ja mitmed postitused julgustavad märkide üle rõõmustama ja mitte liigselt kahtlema:

Tavaliselt on nii, et märke inglitelt ei tule otsida nad ise tulevad su juurde.

Nad köidavad su tähelepanu igal juhul. Ainus mis siin veel võib viltu minna on, et tundes küll, et see oli märk inglitelt sulle hakkad endas ja inglites, nähtus ja kogetus kahtlema.

\section{Virtuaalne tugirühm headuse õhkkonnas}

Inglitega seonduvad tähendused loovad "headuse õhkkonna", kus anonüümsed kasutajad suhtuvad üksteisesse väga hoolivalt ja armastavalt. Inglipesa pakub seetõttu emotsionaalset tuge, mille näiteks võib tuua kõige arvukamate postitustega foorumi alateema "Kallistamine" (880 vastust). Informatsiooni asemel jagatakse seal positiivseid emotsioone nii verbaalselt kui ka visuaalselt - kümnete kallistavate, paitavate, naeratavate emotikonide abil. Ehkki virtuaalne ja vahendatud, tekitab selline vilkuvate pildikeste virr-varr kasutajate kirjelduste kohaselt neis tugevaid emotsioone: kirjeldatakse, kuidas nii palju "puhast headust" paneb rõõmust nutma või pakub raskel hetkel lohutust.

Lootus saada inglitelt tuge või jagada oma muresid on tõenäoliselt foorumi kasutajaks hakkamise valdav põhimotivaator . Võib arvata, et kasutajad ei ole mujalt leidnud selleks nii sobivat kohta, sümboleid ja keelt. Abi ja toe saamise või paranemise teema esineb ka kasutajate endi kirjeldustes. Näiteks kirjutab kasutaja Südameke rubriigis "Ütleme tere": 
Kuidagi ma siia läbi pisarate oma murtud südame ja katkise hingega sattusin... Ma loodan, et jõudsin just õigesse kohta. Mul on siin kõvasti vaja ennast lappida ja taastada elujõud-mõtted taas õigele teele juhtida...

Sellele postitusele vastavad 11 kasutajat, kes jagavad Südamekesele jõudu ja armastust ning kellest osad viitavad ka endi sarnasele kogemusele. Näiteks Chrissumari kirjutab: "See on tõesti õige koht. Olin ka mina eelmisel aastal väga haige (südamest), kui siia sattusin. Nüüd olen palju tervem - tänu Pesakesele ja mu suhted lähevad juba palju-palju paremini. Seda juhtub ka Sinuga”, või kasutaja Leontine: "Väga paljud meist on siia sattunud katkistena. Juhuseid pole, tähendab oli aeg siia sattuda." Selliste postituste peale tõdeb Südameke: "Ma olen nii õnnetunnet täis... Siin on nii palju siirast headust."

Seega toimib Inglipesas "virtuaalne kogukondlik hoolitsemine"7 (Burrows et al. 2000), mis on omalaadselt kahetasandiline - selles osalevad nii teised foorumiliikmed kui ka inglid. Ühelt poolt pakuvad foorumikasutajad otsest tuge veebisuhtluses, samas kinnitatakse külastajates abstraktsemat usku ja teadmist, et inglid saavad aidata ka päriselus (offline). Nii inglid kui ka heatahtlikud foorumiliikmed aitavad ületada ebakindlust, saada emotsionaalset tuge või tunda end teiste toetaja ja õpetajana. Inimesed jagavad veebis oma muresid, aga ka positiivsust (kallistused, hea energia saatmised jne), seda nii foorumi kasutajatega kui ka inglitega.

Inglitega suhestumine täidabki sageli praktilise religiooni niši, kus inglite abi kuulub justkui käekotti, kust seda vajadusel võtta ja kasutada saab (Utriainen 2014). Võrreldes Soome uuringuga tundub siiski, et Eestis pöördutakse inglite poole pigem üldisematel teraapilistel eesmärkidel. Kui soomlased palusid inglitelt sageli abi näiteks tipptunnil kaubanduskeskuse parklas vaba parkimiskoha leidmiseks (Utriainen 2014), siis Eesti foorumis arutletakse, et ingleid ei tasuks igapäevaste pisiküsimustega tülitada. Utriainen (2014) toob samas välja, et inglid on inimeste jaoks "alati olemas, et pakkuda tunnustust ja seltsi" - nende üleloomulik olemus ja jäägitu lojaalsus muudab nad seetõttu inimestest kindlamateks ja usaldusväärsemateks abistajateks.

\section{Kuidas Inglipesa toimib?}

Inglipesa õhkkond on rõhutatult positiivne. Näiteks foorumi teemas, kus uued liikmed end tutvustavad, vastatakse isegi lühikesele tervitusele nii kallistavate-paitavate emotikonide kui ka heade soovidega. Selline üksteise toetamisele suunatud suhtlemine on veebifoorumites üsna ebatavaline: anonüümses keskkonnas tajuvad kasutajad pigem ohtu sattuda rünnaku alla (Burrows et al. 2000). Näiteks veebiportaal pihid.net annab inimestele justkui võimaluse 
oma isiklikke üleelamisi kurta, ent suures osas on tegu naljalugudega, mille puhul hinnatakse pigem meelelahutuslikkust ning millele kirjutatakse kriitilisi-iroonilisi kommentaare. Sellele leheküljele kirjutatud postitusele tüdruksõbraga tekkinud probleemi kohta (mis tundub olevat foorumisse postitatud siirast murest) vastatakse näiteks: "sittagi ta sind armastab. oled ikka möku küll." Teine kommentaator viitab probleemi ühe põhjustajana kirjutaja väikesele peenisele (“sul on pliiatsmunni sündroom”), kolmas nimetab seda pubeka maailmavaluks ("Proovi www.lapsemure.ee. See pole siin pubekate nõustamiskeskus"). Neljast kommentaarist vaid üks püüab kirjutajat lohutada ja toetada. Ka Eesti vaimsete-esoteeriliste foorumite puhul on välja toodud, et keskkondade anonüümsus ei mõju kasutajatele distsiplineerivalt: foorumites otsitakse eelkõige võimalust oma teadmisi näidata (Hiiemäe 2013).

Inglipesa eristub teistest veebikeskkondadest ning võib välja tuua mitmeid mehhanisme, mis aitavad sealset empaatilist ja hoolivat "headuse keskkonda" hoida. Esiteks tugev modereerimine ja kindlad reeglid. Juba foorumi manifestis kirjutab Kaledon lahti veebilehe keskse idee toetava ning positiivse keskkonnana:

See foorum pole koht, kus Sind halvustatakse, Sinu probleemide või imeliste müstiliste kogemuste üle naerdakse ja kurjustatakse, Sulle oma uskumusi peale surutakse. Võtame iga uue liikme ja kogemuse vastu avali käte, heade soovide ning naeratusega. Siin võid sa olla just see, kes sisimas oled. ${ }^{8}$

Inglite-väärilise keskkonna hoidmise vajadus on oluline argument reeglite järgimiseks ning õigustus kõrvaldada postitused, mis keskkonna "kõrgvibratsioonilisust" häirivad. Ebasobivad kommentaarid kustutatakse, ebasobiva nimega (nt Saatan) kasutajatel ei lubata end registreerida. Tugev modereerimine tekitab ka vastuolusid: 2012. aasta kevadel foorumis pettunud ning sealt lahkunud kasutaja(d) kirjutas(id) teistes veebifoorumites Inglipesa kohta mitmeid negatiivseid kommentaare. Üldiselt aga on kasutajad reeglid omaks võtnud ning peavad neid Pesakese hoidmise jaoks vajalikuks.

Teiseks aitab Inglipesa erilisele olemusele kaasa kogukonnale iseloomulik sõnavara ja stiil. Retoorilistest konstruktsioonidest võib välja tuua näiteks kodu ja puhastamise metafoorid. Juba Inglipesa nimi viitab enamale kui pelgalt virtuaalsele foorumile. Pesa ja kodu kujundit rõhutatakse üsna sageli, mis loob kasutajates arusaama paiga erilisusest, mida on foorumis ka otsesõnu väljendanud: "Meil on siin ikka eriline Pesake, pole enne kuulnud, et ühestki foorumist nii palju hoolitakse, korrastatakse ja puhastatakse." Lisaks foorumi tekstide "puhastamisele", mis tähendab oma postituste tagantjärele ülevaatamist ja keelelist korrigeerimist, toimuvad alates 2011. aasta aprillist regulaarselt ka 
Pesa energeetilised puhastamised. Kaledon selgitab: "Puhastame kogu foorumi kogunenud energeetilisest mustusest ja tugevdame kaitseid, et pahatahtlikkus jääks väljapoole pesauksekest - '. See tähendab, et kasutajad saadavad Pesale valgust ja armastust, sest nagu üks kasutaja rõhutab: "kallis Pesake ootab meie kõigi hellitavaid ning jõudu andvaid paisid ning kallisid!”. Sellised tegevused ja Inglipesa kirjeldamiseks kasutatavad sõnad loovad arusaama Pesast kui igaühe jagatud kodust, mida tuleb hoida ja korrastada ning kus kõik kasutajad (ja ehk ka inglid?) moodustavad justkui ühise perekonna.

Ka kogu Inglipesa suhtlust vormivat "headuse keelt" võib näha retoorilise praktikana, mis ühendab keelelise ja visuaalse. Nn "inglite keel” avaldubki ka näiteks eredates värvides, rõhutatult pehmetes-helgetes New Age'i stiilis piltides; ohtras spetsiaalsete, sageli ingleid kujutavate emotikonide kasutamises jne. Enese ja oma maailmanägemuse defineerimine valguse, pehmuse, värvilisuse kaudu avaldub tekstides, aga ka kasutajate nimedes (üks aktiivsemaid foorumi liikmeid kannab näiteks nime Vikerkaarevärvi Pallike). Sageli esineb sõnade hellitusvorme ning rõhutatult positiivset sõnavara. Lehekülje päises tervitatakse kasutajaid kutsudes neid "imeliseks" ning tervitussoovidega nagu "Sinu kaitseingel ei jäta sind kunagi maha", "Sa oled armastatud ja hoitud" või "Inglid armastavad sind tingimusteta". Moderaator Kaledon kasutab keskkonna kirjeldamiseks kokkuvõtvalt mõisteid "heatahtlik ja kõrgvibratsiooniline".

Keskkonna üldine tonaalsus annab ette tugeva standardi, mida külalised püüavad järgida. Siin on kõnekas ühe uue foorumi liikme esimene tervitus, milles ta väljendab selgelt tajutud normi pesakeses valitsevast erilisest keelest ja stiilist, mis tekitab temas "kõhklust, kas oskan ikka tundeid, mõtteid nii ilusasti lausetesse sättida ning õrnalt väljendada nagu teil siin on kombeks".

Selline empaatiale ülesehitatud suhtlemisstiil läheb sügavamale kui lihtsalt retoorika. Järgnev analüüs on pühendatud erilise epistemoloogilise positsiooni iseloomustamiseks, mis Inglipesa ning uut vaimsust kui diskursiivset kogukonda ka mõneti laiemalt iseloomustab.

\section{Headuse, naiseliku pehmuse keskkond}

Inglid ning headuse ja pehmuse rõhutamine seondub kultuurilise stereotüübiga naiselikkusest. Inglitega seotud tegevused ja sümbolid moodustavad koherentse terviku: empaatilise murede kuulamise ja jagamise juurde kuulub pehmuse ja teistega arvestamise retoorika ning sümboolika. Ka on varasemates uuringutes näidatud, et kui meessoost kasutajad hindavad internetisuhtluses võimalust vaielda, siis naised otsivad pigem konsensust (Lövheim 2004). Loomulikult ei ole sellised mustrid üldkehtivad, vaid pigem teatud konventsioonid, mille 
puhul mehelikkuse ja naiselikkuse sildi kasutamine on tinglik. Seega ei püüa käesolev uuring lahterdada erinevaid suhtlemisstiile soopõhiselt, vaid esitleb Inglipesa kui näidet, kuidas toimib teatud kultuurilistel mustritel põhinev kommunikatsiooni- ja suhteskeem. See haakub varasemates uuringutes väljatoodud sugudepõhiselt eristavas mudelis nn naiseliku suhtlemise ja maailmaga suhestumise viisiga.

Statistika kohaselt on Inglipesa leheküljel naisi ligi kuus korda rohkem kui mehi (suur osa liikmeid on jätnud oma soo märkimata, mistõttu ei pruugi see olla siiski tegelik näitaja). Naiste suurem osakaal inglitega seonduvates praktikates ei ole iseenesest üllatav. Ka varasemates uuringutes on näidatud, et inglid on populaarsed eelkõige naiste seas (Gilhus 2012) või et naised palvetavad rohkem inglite poole (Cerulo \& Barra 2008). Utriainen (2014) nimetab uue vaimsuse ingliteraapiaid koguni "naiste teraapiliseks religiooniks". Sugudepõhine vahe ilmneb ka Eestis läbi viidud küsitlustes: väitega, et "on olemas inglid, kes aitavad ja kaitsevad meid" ei nõustunud või pigem ei nõustunud alla kolmandiku naisi (28,7\%), meestest aga umbes pooled (Jõks 2012).

Inglipesas nähtuvad soostereotüüpsed arusaamad on pigem traditsioonilised, ehkki mitmed uusreligioonide uurijad on näidanud, et paljudel juhtudel on religioossete-vaimsete rühmade üks alusprintsiipe vastandumine patriarhaalsetele soorollidele ning püüd käsitleda naise olemust ja naiselikkust maailmareligioonidest erinevalt. Nii näiteks sümboliseerib naise keha Wicca Jumalanna kultuses võimast (seksuaalset) väge (Greenwood 2000), feministlikud nõialiikumised toetuvad tsüklilise muutumise (sünd, kasv ja vananemine) ideele, mis haakub rohkem "naiseliku vaimsusega" (Luhrmann 1989: 52). Siiski sõltub isegi sellistes kogukondades soodünaamika palju konkreetsest rühmast ja selle juhtfiguuridest, kes sageli on siiski mehed (Greenwood 2000). Inglipesa tundub sümboolikalt ja väärtustelt Jumalanna kultuse jõulisele "feminiinsele vaimsusele" pigem vastanduvat: Pesakese kasutajad on valdavalt naised, kes toetuvad klassikalistele soostereotüüpidele, tähtsustades pehmust, hoolivust ja empaatiat. Siiski võib näha, kuidas kasutajad leiavad tuge soostereotüüpe ületamata. Inglitel on siin tähtis roll.

Inglid kui sümbolid ja eeskujud toetavad Pesakese erilist õhkkonda nii oma tähenduste (kaitseingel; ingel kui roosapõskne lapsuke; inglisulgede pehmus) kui ka tajutud läheduse tõttu (isegi kristlikus käsitluses on nad küll jumalikud olendid, kuid käivad siiski ka maa peal inimeste juures). Varasemad palvetamise teemal tehtud uuringud on näidanud, et inimesed valivad palve objekti oma sotsiaalse positsiooni järgi. Need, kes tunnetavad enda staatust madalana - ja kes Cerulo ja Barra (2008) uuringus olid eelkõige keskmisest madalama palgaga naised - eelistavad palvetada mitte otse jumala (kõrgema jõu) poole, vaid valivad vahendajaks näiteks inglid, neitsi Maarja või mõne 
pühaku, kellega tajutakse teatavat sarnasust. Palve adressaadi valimisel ongi oluline arvatav tõenäosus, et see, kelle poole palvetatakse, palvele ka vastab (Cerulo \& Barra 2008).

Suhe ingli(te)ga on Pesakeses konstrueeritud pigem siira ja sügava sõprusena, kus Ingel võib olla küll inimesest võimsam, ent mitte taevane sõdur, autoritaarne isa- või mehekuju. Mitmetel puhkudel loob ingel kasutajale rollimudeli - ta on kasutaja ideaalne mina selle kõrgemas, täiuslikus vormis. Postitustes väljendatakse ka otseselt, et mõni eriti hästi kirjutatud sõnum või soov pidi tulema tavamaailmast kõrgemalt (inglitelt): "su postitusest õhkub nii palju hellust, armastust, justkui oleks see Inglitelt, ju siis ongi; Imeliselt kerge tunne hakkas seda lugedes." Viited kasutajate ingellikule olemusele esinevad ka mujal. Näiteks foorumi päisesse ilmuvate tervitustekstide seas on otseselt ingellikkusele viitav: "Tere, imeline [kasutajanimi]! Kas sa täna Inglit oled näinud? Ei ole? Vaata peeglisse, siis näed!” või kaudsemalt selle ideega mängiv "Sa oled tiibadega, võid lennata kaugele ja kõrgele!”. Internetisuhtlus pakubki võimalust võtta argielust erinevaid rolle, mis Inglipesas on rõhutatult positiivsed; võimalust olla aitaja, lohutaja, jagada armastust ning teada, et vajadusel võid teistelt tuge saada. Teisalt on uuringutes järeldatud, et vaimsed praktikad võimaldavad ka üldisemalt oma järgijatel muutuda "teistsuguseks sellest, kes nad arvasid end olevat, et jätta maha lootusetusetunne" (Collett 2003: 84). Inglipesas liitub sellega virtuaalruumile omane mängulisus ja rollide paindlikkus. Mõnevõrra paradoksaalselt rõhutavad mitmed Inglipesa kasutajad, et just seal saavad olla "kõik inimesed need, kes nad tõeliselt on", ehk siis just tavaelu ei võimalda "päris enesena olemist" ja anonüümses virtuaalkeskkonnas avaldub inimese tegelik mina. Selline arusaam lisab Inglipesas toimuvale kaalu ja tähenduslikkust.

Pesakeses loodav ja kultiveeritav empaatiline ja alati-abistamiseks-valmis tavapärasest parem "mina" on see osa endast, millest lähtuvalt teiste kasutajatega suheldakse. See hooliv ja läbinisti heatahtlik roll ühendab ka võimu ja jõu, mida ingel kahtlematult sümboliseerib. Kapitalistlikus edule orienteeritud, maskuliinsete väärtustega maailmas annab inglite kohalolu jõulisema tähenduse traditsiooniliselt naistega seostatavatele käitumismallidele nagu abistamine ja hoolimine.

\section{Subjektivistid ja seostatult teadjad}

Erinevalt kristlusest ei näe uue vaimsuse ideestik lõhet maise ja taevase sfääri vahel, loobutakse patu käsitlemisest inimloomuse paratamatu osana (Altnurme 2013). Inglipesa manifestis rõhutab Kaledon, et "Inimese loomulik olek on õnne- 
likkuse tunne. Usume, et Maal ongi paradiis ja Inimene on osake Kõige Loojast ning vanemale sarnase olemusega". Uue vaimsuse õpetustes rõhutatakse keskse printsiibina igaühe rolli oma elu eesmärkide saavutamisel. Suunates inimesi positiivselt mõtlema, kinnitatakse loomupärast õigust õnnele ja rahulolule. Näiteks kasutaja La Luna kurdab rubriigis "Minu kogemus Karmainglitega", et "Kardan natuke ÄKKI ma ei saagi vabaks $\mathscr{\circ}$ ", ${ }^{9}$ mille peale kasutaja Mari vastab kohe: "Muidugi saad, sellist varianti ei ole, et ei saa. See on kirjas Universumi seadustes, kes küsib, sellele antakse." Siin avaldub uue vaimsuse keskkonnas levinud hinnang maailma toimimise kohta, mille kohaselt inimestel on loomupärane õigus saada seda, mida nad tahavad.

Vähemalt seisukohtade tasandil rõhutatakse ka igaühe võrdsust, mille Kaledon toob eraldi välja foorumi manifestis:

Me usume, et energiate nägemine, tunnetamine, energeetiliste olenditega suhtlemine, hingena rändamine, ravivõimed ja kõik muu imeliselt müstiline on iga Inimese loomulikud anded.

Selle printsiibiga ei ühti uue vaimsuse keskkonnas leviv teenuse osutamise loogika, kus "spetsialistid" müüvad oma erivõimeid ja vahendavad ka inglite abi. Teenuste reklaami on Inglipesale ka ette heidetud. 2012. aasta kevadel foorumis pettunud ning sealt lahkunud kasutaja kurtis mitmes teises foorumis, et Inglipesa on halva energeetikaga ning selle põhieesmärk on müüa inimestele kalleid teraapiaid. Tõepoolest, foorumist võis leida viiteid ka tasulistele teenustele nagu Inglituba ja ingliteraapiad, mida mõned foorumi aktiivsed liikmed pakkusid. Aprillis 2012 lisas Kaledon foorumi reeglitesse puhastusteenuste reklaamimise keelu.

Alates foorumi loomisajast on olnud foorumi üks suurtest missioonidest opetamine inimestele, kuidas ise ennast puhastada ja saada piisavalt taskakaalu, et jäöda vastupidavaks energeetiliste jõudude mõjutustele. Ma usun, et iga inimene on võimeline omal jõul saama üle mustusest, mis teda pärsib ja mõjutab, ilma välise puhastuseta. Oleme ju kõik samaväärsed Jumala lapsed. Üritame olla inimestele toeks nii palju, kui suudame - õpetame, anname nõu, saadame valgust ja oleme toeks. Anname oma parima, et inimesed suudaksid ise muuta oma elu ja hinge õnnelikuks, rõõmsaks ja säravaks.

Edasine tugev modereerimine on aidanud lehel vältida reklaamikanaliks muutumist. Mitmel puhul kirjeldavad foorumi kasutajad Inglipesa kui kalliste vaimsete teraapiate väärtuslikku alternatiivi. Seega vastandub pesake "vaimsele teenusteturule" (Bowman 1999: 188), kus teraapiate ja teenuste eest tuleb maksta, ning püüab anda igaühele võimaluse suhelda inglitega ja lahendada 
oma probleeme ise. Vähemalt suhtumiste väljendatud tasandil ei ole Inglipesas liidreid või keelajaid-käskijaid, ehkki tegelikkuses on foorumis rollid välja kujunenud - eelkõige mitteformaalselt, aga ka formaalselt (näiteks antakse aktiivsusest lähtuvalt igale liikmele oma staatus - alates noorliikmest kuni superliikmete ja "foorumi kangelasteni").

Inglitega suhtlemisel tajutakse olulisena võrdsust ja igaühe väärtustamist. Näiteks kasutaja Erela rõhutab iga oma postituse juurde ilmuvas signatuuris sõnaselgelt igaühe võrdsust inglitega suhestumisel:

Inglitega suhtlemiseks on meil kõigil ühesugune võime, sest oleme vaimses mõttes ühtmoodi “andekad”. Kui tundubki, et keegi on selles vallas teistest andekam, on ta lihtsalt õigel ajal uskunud ja usaldanud oma tajusid.

Sellest tsitaadist nähtub, et andekusena tõlgendatakse eelkõige oma tajude usaldamist, mis illustreerib autoriteedi nihkumist subjektiivsele kogemuseletajule ning haakub laiema uusvaimse põhimõttega isikliku kogemuse väärtustamisest. Inglipesa vestlustes rõhutatakse kogemuse ja subjektiivse tunde ülimuslikkust tõeväärtuse üle otsustamisel. Kõvakaaneline rohkete värviliste illustratsioonidega tõlgitud ingliraamat (Astell 2006: 9), millele foorumis viidatakse, toob olulisena välja Emanuel Swedenbergi (1688-1772) tsitaadi:

Ma tean suurepäraselt, et paljud ütlevad, et mitte keegi ei saa hingede ja inglitega rääkida senikaua, kuni ta oma kehas elab; ja paljud räägivad, et see kõik on kujutlusvõime vili... ja teised toovad teisi vastuväiteid. Kuid see kõik ei puuduta mind, sest mina olen näinud, ma olen kuulnud, ma olen tundnud.

Seega peaks inimene usaldama oma isiklikku kogemust isegi juhul, kui see satub konflikti üldtuntud ja/või autoriteetsete seisukohtadega.

Samasugust epistemoloogilist positsiooni on kirjeldatud (vt Belenky et al. 1997) kui subjektivismi ja seostatud teadmist (connected knowing). Seostatud teadjad on subjektivistid, kes usuvad et tõde on "isiklik, eriline ja vahetul kogemusel tuginev" (Belenky et al. 1997: 113). Blythe McVicker Clinchy kirjeldab (1994: 34) subjektiviste nii:

Nad vaatavad endasse, otsides teadmisi. Nad on iseenda autoriteedid. Oma isikliku tõe leiavad nad südame või kõhutunde kaudu. [...] Usaldatakse kogemuste põhjal kujunenud kõhutunnet-intuitsiooni, mitte niiöelda autoriteete, kes teesklevad kõige teadmist ja pü̈̈avad oma ideid peale suruda. Subjektivist otsustab tunnete põhjal: mõte on õige, kui see tundub õige. 
Belenky jt (1997) või Clinchy (1994) uurimustes kirjeldatud positsioon iseloomustab väga täpselt ka suhtlust Inglipesas. Subjektivist toetub teadmistele, mis on saadud isiklikust kogemusest. Ideaalis ongi inglid abilisteks, kes annavad inimestele jõudu leida lahendusi ja vastuseid, mitte ei ütle ette valmis vastuseid. Subjektivistid nihutavad autoriteete: tunnetuslikult ei toetu nad ohustavale, negatiivsele teadmisele, mis pärineb institutsionaalsetelt ekspertidelt, vaid lähedaste (naiste puhul sageli just naissoost) sõprade ja suhtlusringkonna seisukohtadele (Hammer 2010: 57). Niimoodi kujundatakse väga tugev tõepositsioon ning ollakse oma seisukohas veendunud isegi siis, kui modernsed autoriteedid (nagu teadus või meditsiin) seda ei kinnita (Belenky et al. 1997). Pesakeses toimuv haakub laiemalt hilismodernse ebakindlusega (vt Giddens 1991): nii on näiteks internet kui infokanal tõusnud tervisega seotud otsuste langetamisel üheks olulisemaks allikaks, mis viitab tendentsile, et inimesed püüavad leida teavet teiste inimeste kogemuste kohta ega lepi vaid arsti kui eksperdi arvamusega (Burrows et al. 2000).

Usaldamatust ametlike institutsioonide vastu illustreerib näiteks suurliikme Melodia enne 2011. aasta rahvaloendust püstitatud alateema "Mida te arvate Rahva ja eluruumide loendusest?". Ta kirjutab: "Mulle tuli koju selline voldik, et toimub rahva ja eluruumide loendus. Ja see on kohustuslik kõigile. Millegipärast hakkas mulle see nii vastu, et kohe süda läks pahaks sellest mõttest." Sedavõrd tugev, koguni füüsilisena kirjeldatud reaktsioon riigi poolt ette nähtud kohustuse vastu näitab ühelt poolt usaldamatust, teisalt soovi ise otsustada. Ehkki üldiselt püütakse Inglipesas Melodia hirmu leevendada ning suhtutakse loendusesse neutraalselt või isegi positiivselt, kurdab üks vastaja samuti, et "sõna "kohustuslik" tähendab, et vastu vaielda ei tohi ja polegi kellegagi vaielda...puudub vaba tahe...". Ka kasutaja Õppija arutleb:

... ma isiklikult ei tunne end turvaliselt loenduse suhtes. Ma ei oska seda isegi täpsemini seletada. Pole otseselt hirm, aga karjalooma tunne tekib. Samas olen aga kindel, et eks seda tulemust tahetakse minu huvides kasutada. Võib olla on see tunne pärit sellest, et loendus pole vabatahtlik.

Siin avaldub otseselt uue vaimsuse individuaalsust hindav väärtushoiak, kus "karjaloomana käitumist" ja autoriteetide pimesi usaldamist nähakse probleemina. Ka moderaator Kaledon tõdeb rahvaloenduse teema all, et "sunnitud asjad pole kunagi kõrge vibratsiooniga".

Selline tendents tõstatab küsimuse nihkuvatest autoriteetidest: kui suured modernsed autoriteediallikad nagu teadus või meditsiin usaldusväärsust kaotavad, siis kuidas seda kompenseeritakse? Tõenäoliselt tähendab see ka just Inglipesa-taoliste kanalite suuremat rolli ning seal jagatavate kogemuslugude järgi otsustamist. Argiusundilised tähendused ringlevadki üldiselt lugudepõ- 
hiselt (Draper \& Baker 2011). Clinchy (1994: 39) rõhutab samuti narratiivi olulisust, sest seostavad teadjad "otsivad idee taga lugu”. Kui eraldav teadmine tähtsustab argumenti ja vaidlemist, siis seostavalt teadjad jutustavad lugusid. Ehkki uue vaimsuse järgijad peavad oluliseks vahetust kogemusest tulenevat teadmist ja tõde, pole reaalsuses kõige oma nahal läbi proovimine võimalik, mistõttu nähakse usaldusväärsena ka oma tuttavate või endaga sarnaste inimeste kogemusi (Hammer 2010). Inglifoorumis on väga suur osa omavahelisest suhtlusest edasi antud narratiivses vormis: maailma seletatakse ja teistele antakse nõu oma või lähedaste elust pärit lugude põhjal. See illustreerib üldisemat tendentsi uue vaimsuse miljöös, kus autoriteet nihkub subjektiivsele kogemusele ja tajule ning haakub laiema uusvaimse põhimõttega isikliku kogemuse väärtustamisest. Sellised teiste kasutajate lood, mille mustrid on sarnased (näiteks vaimse õpetuse leidmise ja vastuvõtmise puhul) võivad kujundada ka inimeste endi kogemusi, sest annavad ette mingi normi ja struktuuri, kuidas midagi kogeda. Säärast tendentsi võib märgata näiteks inglite ja nende saadetud märkide tajumisel headuse ja soojusena, mida Inglipesas avaldatud kogemuslood väga tugevalt kinnistavad.

\section{Kokkuvõte}

Inglipesa kui aktiivne virtuaalne keskkond võimaldab vaadelda online-suhtlusel põhineva tugirühma toimimist ning vaimsete-religioossete tähenduste loomise protsesse. Diskursiivsele kogukonnale iseloomulikult on Inglipesas kujunenud välja oma kommunikatiivne stiil ning praktikad, millega kogukonda luuakse ja hoitakse. Omavahelises suhtluses toimiv nn hoolivuse keel kujundab subjektivistliku ja seostatud teadmise positsiooni ning võimaldab foorumi liikmetel saada teraapilist tuge. Foorum näitlikustabki tänapäevaste inglikujutelmade rolli uue vaimsuse miljöös. Sümbolitena (või ka tegelike abiliste-juhendajatena) suudavad inglid võtta sobilikke tähendusi; nende toel täidab Inglipesa foorum olulisi funktsioone kasutajatele emotsionaalse toe jagamisel ning argiusundis tähendusliku loomisel ja kinnitamisel. Kristlike sümbolitena kannavad inglid teataval määral ka kristlikke väärtusi, nende olemuse defineerimisel on autoriteetideks aga kiriku asemel hoopis teised foorumikasutajad.

Juba ingleid defineeriv omadus on nende heatahtlikkus ja "kõrgvibratsioonilisus", mis avaldub inglite ilmumishetkel või neilt saadetud märkide puhul äratuntava soojuse, headuse ja positiivsete emotsioonidena. Erilist soojust ja headust tajutakse ühtaegu nii ingli kohaloleku tulemi kui ka olulise tõendina, mille põhjal otsustada, et tegemist tõepoolest oli ingliga. Inglipesas jagatud lood julgustavad lugejaid tähele panema inglite saadetud märke, mis omakorda 
toob kaasa siira rõõmu nende ilmumisel. Seetõttu võib ühel hetkel taevast langev valge sulg tõepoolest muuta maailma sõbralikumaks ja elamisväärsemaks paigaks. Inglipesas jagatud kogemuslood annavad sellistele märkidele kaalu ja kinnitavad kogemuse erilisust.

Ehkki suhteline anonüümsus, tugev modereerimine ja reeglid tekitavad Inglipesa kasutajate seas tunde turvalisest paigast, on siiski tegemist veebisuhtlusega, kus peituvad ka ohud. Tuleb näiteks arvestada, et Inglipesa on virtuaalne keskkond, kuhu sisenedes võidakse probleemid küll maha jätta, kuid nendega tuleb tavamaailma tagasi pöördudes paratamatult taas tegeleda. Online kogukond, mis tundub olevat päriselust paremgi, võib tekitada ka kiusatuse veeta seal üha rohkem aega. Ehkki selline ebaterve eskapism ei olnud käesoleva artikli fookuses, tuli paarist intervjuust välja, et ka Inglipesas tajutakse probleemina kasutajaid, kes tunduvad veetvat foorumis liiga palju aega. Internetieskapism (sh Inglipesa-taolistes kogukondades) vajaks eraldi käsitlemist. Inglipesa kui uue vaimsuse tähendusi loov keskkond on samas siiski küllaltki eriline näide, sest see laiendab teataval määral virtuaalkeskkonnas jagatavat tuge reaalsesse maailma, kinnitades kasutajates usku, et inglid kui võimsad ja heatahtlikud olendid saavad inimesi ka tavaelus aidata.

Inglipesa õhkkond ja suhtlemisviis eristuvad teistest internetikeskkondadest. Foorumis ei kritiseerita teisi kasutajaid, neile jagatakse hoopis tuge või headust ja julgustatakse raskustest üle saama. Selline suhtlemisstiil ja lehekülje üldine tonaalsus toetavad seostatud teadmise mudelit, mis ei tähtsusta argumenti, vaid omavahelist suhet ja kogemust. Lehekülje alusprintsiip on empaatia ja hoolivus teiste ideede ja isiklike muredega suhestumisel: eriline "kõrgvibratsiooniline" headus, mida toetab inglite kui murede kuulajate ja lohutajate sümboolne kohalolu. Inglipesa loobki omalaadse mitmetasandilise virtuaalvõrgustiku, kus inglid toimivad kui olulised "kõrgvibratsioonilised" valvurid, mis aitab luua kasutajate vahel turvalist lähedust. Inglid on sedavõrd heatahtlikud ja hoolivad, et neilt kui "kõrgematelt" olenditelt otse saadava toe kõrval annab nende kohalolu kindluse, et foorumi teised kasutajad, ehkki mitte päris inglid, vähemalt püüdlevad inglite-väärilise headuse poole. Teisalt demonstreerivad inglid ja "ingellik suhtumine" üldisemalt, et ka väge ja võimu omades võib maailma ja inimestesse suhtuda hoolivalt ja armastavalt. Seetõttu on inglid kujunenud sümboliks inimsuhteid väärtustava ning laiemalt uue vaimsusega seonduvate väärtuste (individualistlik eneseareng; holistiline ja hooliv suhtumine maailma ja inimesse) ning maailmaga suhestumise viiside (subjektivism või seostatud teadmine) kandmisel ja legitimeerimisel. 


\section{Kommentaarid}

1 Inglite suur populaarsus ei ole iseloomulik ainult Eestile. Ameeriklased näitavad küsitlustes kõrget inglitesse uskumise taset: koguni 78 protsenti arvab, et inglid mõjutavad inimeste elusid (Cerulo \& Barra 2008: 378). Brittidest usub inglitesse 41 protsenti, mis on kõrgem tulemus kui aastal 1939, mil selleteemaliste regulaarsete küsitlustega alustati (Woodhead 2012).

${ }^{2}$ Kristlike sümbolite laialdane levik uusvaimses keskkonnas tähendab kirikule keerulist dilemmat. Ühelt poolt võib vaimsuse esiletõusus näha positiivset indikaatorit inimeste sisemisest vajadusest vaimsuse järele ja tõestust religioossuse olulisusest vastuseks väidetavale sekulaarsusele või ateismile. Teisalt nähakse kristlike sümbolite teisenemist uusvaimsetes õpetustes probleemina. Kirik peab tõdema, et tal ei ole isegi kristliku taustaga sümbolitele monopoli ja ta ei saa nende kasutamist kontrollida. Eriti huvitavad on katoliku kiriku seisukohad uusvaimse müstika suhtes, sest seal on ühisosa suurem - toetutakse rohkem rituaalsusele, müstilisusele, traditsioonile ning taotletakse elumaailmade (taas-)spiritualiseerimist (Dinges 2004). Võrreldes luterliku kirikuga on Vatikan esitanud aktiivsemalt ametlikke seisukohti, kus esinevad viited religiooni reostumisele, nähakse probleemi üha enam kaduvas institutsionaalses kontrollis (Dinges 2004: 273). Vatikan leiab, et sünkretistlike usundimustrite esilekerkimine on niihästi kristliku identiteedi hajumise põhjus kui ka tagajärg. Samas on katoliku või mitmete evangeelsete protestantlike kirikute püüd end puhastada ja kontrollida argiusundilisi malle suurendanud lõhet kiriku ja inimeste vahel (Woodhead 2013). Kirikul on oluline, ent samas keeruline eristada ingleid kristlikus kontekstis ja uues vaimsuses. Näiteks katoliku kaplan Dominic White rõhutab (2005), et korrektne oleks käsitleda ingleid sõnumitoojatena, mitte eraldi subjektina. Siin avaldub võitlus "ehtsa" kogemuse määratlemise üle: kellel on õigus mõtestada ingleid kui tänapäeva maailma kõnekaid sümboleid? Kas katoliiklik teoloog või kiriku esindaja saab väita, et inimesed, kes kogevad uue vaimsuse tüüpi ingleid, eksivad?

3 Statistika kohaselt kasutas 2012. aastal 16-74aastastest elanikest internetti ligi 80 protsenti, kodune arvuti ja internetiühendus oli 75\% leibkondadest (Sikkut 2012).

4 Toodud näitajad on võetud lehekülje ametlikust statistikast augustis 2013.

5 Tekstinäited siin ja edaspidi pärinevad Inglipesa foorumist ning on esitatud muutmata kujul.

6 Selles avaldub olemuslik erinevus kristlike ja uue vaimsuse inglite vahel. Kui kristlikus kontekstis on ingel tajutud jumala sõnumitooja ja inimeste hoiatajana, siis uusvaimsed inglid viibivad inimestega püsivamalt ning käituvad pigem kui personaalsed abistajad-sõbrad.

7 Burrows jt (2000) kasutavad seda mõistet (virtual community care) terviseteemaliste veebilehtede analüüsil.

8 Inglipesa üheks alusarusaamaks on inimeste olemuslik headus. Implitsiidselt toimub positiivne enesesisendus, kus rõhutatakse, et tegelikult oleme kõik sisimas head, justkui inglid - see on inimese tõeline olemus. Nii moderaator kui ka kasutajad püüavad seda kuvandit hoida ja sellest lähtuvalt käituda.

9 Kasutaja peab siin silmas halba karmat ja karmavõlga, millest vabanemise olulisust mitmed uue vaimsuse õpetused rõhutavad. 


\section{Kirjandus}

Altnurme, Lea 2012. Mida võiks kirik teada eestimaalase individuaalsest religioossusest. Jõks, Eerik (toim). Astu alla rahva hulka. Artikleid ja arutlusi Eesti elanikkonna vaimulaadist. Tallinn: Eesti Kirikute Nõukogu, lk 193-212.

Altnurme, Lea 2013. Uus vaimsus - mis see on? Uibu, Marko (toim). Mitut usku Eesti III: Uue vaimsuse eri. Tartu: Tartu Ülikooli kirjastus, lk 18-36.

Astell, Christine 2006. Inglid. Tarkus. Ravimine. Saatus. Tallinn: Varrak.

Beaulieu, Anne 2004. Mediating Ethnography: Objectivity and the Making of Ethnographies of the Internet. Social Epistemology 18 (2-3), lk 139-163 (doi: 10.1080/0269172042000249264).

Belenky, Mary Field \& Clinchy, Blythe McVicker \& Goldberger, Nancy Rule \& Tarule, Jill Mattuck 1997. Women's Ways of Knowing: The Development of Self, Voice, and Mind. (10th anniversary edition.) New York: Basic Books.

Bowman, Marion 1999. Healing in the Spiritual Marketplace: Consumers, Courses and Credentialism. Social Compass 46 (2), lk 181-189 (doi: 10.1177/003776899046002007).

Budka, Philipp \& Kremser, Manfred 2004. CyberAnthropology - Anthropology of CyberCulture. Khittel, Stefan \& Plankensteiner, Barbara \& Six-Hohenbalken, Maria (toim). Contemporary Issues in Socio-Cultural Anthropology: Perspectives and Research Activities from Austria. Wien: Löcker, lk 213-226 (http://www.philbu.net/budka_kremser_ cyberanthro.pdf - 27. märts 2014).

Burrows, Roger \& Nettleton, Sarah \& Pleace, Nicholas \& Loader, Brian \& Muncer, Steven 2000. Virtual Community Care? Social Policy and the Emergence of Computer Mediated Social Support. Information, Communication and Society 3 (1), lk 95-121 (doi: 10.1080/136911800359446).

Cerulo, Karen A. \& Barra, Andrea 2008. In the Name of...: Legitimate Interactants in the Dialogue of Prayer. Poetics 36 (5-6), lk 374-388 (doi: 10.1016/j.poetic.2008.06.010).

Clinchy, Blythe McVicker 1994. On Critical Thinking and Connected Knowing. Walters, Kerry S. (toim). Re-Thinking Reason: New Perspectives in Critical Thinking. Albany, NY: State University of New York Press, lk 33-42.

Collett, Joan Elizabeth 2003. Empowering the Unempowered: A Narrative Approach to Deconstructing Spirituality with Women Experiencing Abuse. A Master Dissertation. (http://uir.unisa.ac.za/handle/10500/1843 - 27. märts 2014).

Dinges, William D. 2004. The New (Old) Age Movement: Assessing a Vatican Assessment. Journal of Contemporary Religion 19 (3), lk 273-288 (doi: 10.1080/1353790042000266318).

Draper, Scott \& Baker, Joseph O. 2011. Angelic Belief as American Folk Religion. Sociological Forum 26 (3), lk 623-643 (doi: 10.1111/j.1573-7861.2011.01265.x).

Gardella, Peter 2007. American Angels: Useful Spirits in the Material World. Kansas: University Press of Kansas.

Giddens, Anthony 1991. Modernity and Self-Identity: Self and Society in the Late Modern Age. Cambridge: Polity Press; Oxford: Blackwell Publishers. 
Gilhus, Ingvild Sælid 2012. Angels in Norway: Religious border-crossers and bordermarkers. Bowman, Marion \& Valk, Ülo (toim). Vernacular Religion in Everyday life. Sheffield \& Oakville: Equinox, lk 230-245.

Greenwood, Susan 2000. Magic, Witchcraft and the Otherworld: An Anthropology. Oxford $\&$ New York: Berg Publishers.

Hammer, Olav 2010. I Did It My Way? Individual Choice and Social Conformity in New Age Religion. Aupers, Stef \& Houtman, Dick (toim). Religions of Modernity: Relocating the Sacred to the Self and the Digital. Leiden; Boston, MA: Brill, lk 49-68 (doi: 10.1163/ ej.9789004184510.i-273.19).

Hiiemäe, Reet 2012. Taevasest teenäitajast kommertsmaailma sõnumitoojaks: ingli stereotüübid tarbijareklaamides. Mäetagused 51, lk 113-128 (doi: 10.7592/MT2012.51. hiiemae).

Hiiemäe, Reet 2013. Rollid ja rollikäitumine interneti esoteerikafoorumites. Kõiva, Mare (toim). Maailm ja multitasking. Tartu: Eesti Kirjandusmuuseumi Teaduskirjastus (lk 109-132).

Hine, Christine 2000. Virtual Ethnography. Thousand Oaks, CA \& London \& New Delhi: Sage Publications.

Jõks, Eerik (toim) 2012. Astu alla rahva hulka. Artikleid ja arutlusi Eesti elanikkonna vaimulaadist. Tallinn: Eesti Kirikute Nõukogu.

Kozinets, Robert V. 2010 Netnography: Doing Ethnographic Research Online. London; Thousand Oaks, CA; New Delhi: Sage Publications.

Kull, Anne 2004. Inglitest ja institutsioonidest. Usuteaduslik Ajakiri 1 (53), lk 111124 (http://www.usuteadus.ee/failid/UA1_2004/06_UA_1_2004\%2853\%29_Kull.pdf 29. märts 2014).

Luhrmann, Tanya M. 1989. Persuasion of the Witches' Craft: Ritual Magic in Contemporary England. Cambridge, MA: Harvard University Press.

Luhrmann, Tanya M. 2012. When God Talks Back: Understanding the American Evangelical Relationship with God. New York: Alfred A. Knopf.

Lövheim, Mia 2004. Intersecting identities: young people, religion, and interaction on the Internet. Uppsala: Uppsala Universitet.

Markham, Annette N. 2005. The Methods, Politics, and Ethics of Representation in Online Ethnography. Denzin, Norman K. \& Lincoln, Yvonna S. (toim). The SAGE Handbook of Qualitative Research (3. edition). Thousand Oaks, CA \& London \& New Delhi: Sage Publications, lk 793-820.

Noomen, Ineke \& Aupers, Stef \& Houtman, Dick 2011. In Their Own Image? Catholic, Protestant and holistic spiritual appropriations of the Internet. Information, Communication and Society 14 (8), lk 1097-1117 (doi: 10.1080/1369118X.2011.597415).

Paul, Toomas 2008. Inglid läbi aja. Horisont 6, lk 36-41 (http://www.horisont.ee/ node/744 - 28. märts 2014). 
Pekko, Indrek \& Koppel, Katre 2013. Püha kolmainsus kui ema-isa-laps: uus vaimsus ja luteri kirik. Uibu, Marko (toim). Mitut usku Eesti III: Uue vaimsuse eri. Tartu: Tartu Ülikooli kirjastus, lk 139-166.

Potter, Terje 2002. "Räägi minuga inglitest.” Raadiosaade ja inglijuttude situatsioonianalüüs. Lemmeleht. Pro Folkloristica IX. Tartu: Eesti Kirjandusmuuseum, lk 168-180 (http://www.folklore.ee/era/nt/PF9/Potter.htm - 28. märts 2014).

Sikkut, Siim 2012. Ülevaade arvuti- ja internetikasutusest Eestis 2012. Valitsuse tegevusprogramm (http://valitsus.ee/et/valitsus/tegevusprogramm/e-riigist-i-riigiks/ infoyhiskonna-arengu-hetkeseis/arvuti-ja-internetikasutus-eestis-2012 - 13. august 2013, praegu enam kättesaadav ei ole).

Suler, John 2007. The Psychology of Avatars and Graphical Space in Multimedia Chat Communities. The Psychology of Cyberspace (http://users.rider.edu/ suler/psycyber/ psyav.html - 28. märts 2014).

Utriainen, Terhi 2014. Angels, Agency and Emotions: Globalized Therapeutic Religion for Women. Utriainen, Terhi \& Salmesvuori, Päivi (toim). Between Ancestors and Angels: Finnish Women Making Religion. Houndmills: Palgrave Macmillan.

Valk, Ülo 2007. Inglid eesti rahvausundis. Kõiva, Mare (toim). Artikleid usundi- ja kombeloost. Sator 6. Tartu: EKM Teaduskirjastus, lk 77-96 (http://www.folklore.ee/rl/ pubte/ee/sator/sator6/4ylovalk.pdf - 28. märts 2014).

Walter, Tony 2011. Angels Not Souls: Popular Religion in the Online Mourning for British Celebrity Jade Goody. Religion 41 (1), lk 29-51 (doi: 10.1080/0048721X.2011.553138).

Waters, Richard D. \& Tindall, Natalie T. J. 2010. Marketing Churches on the Internet: An Analysis of the Dialogic Potential of Christian Web Sites. International Journal of Nonprofit and Voluntary Sector Marketing 15 (4), lk 369-381 (doi: 10.1002/nvsm.400).

White, Dominic 2005. Are Angels Just a Matter of Faith? New Blackfriars 86 (1006), lk 568-583 (doi: 10.1111/j.0028-4289.2005.00112.x).

Wilson, Samuel M. \& Peterson, Leighton C. 2002. The Anthropology of Online Communities. Annual Review of Anthropology 31, lk 449-467.

Woodhead, Linda 2012. Religion à la mode. The Tablet 28th April.

Woodhead, Linda 2013. Tactical and Strategic Religion. Dessing, Nathal \& Jeldtoft, Nadia \& Nielsen, Jørgen \& Woodhead, Linda (toim). Everyday Lived Islam in Britain. Aldershot: Ashgate. 


\title{
Summary
}

\section{Angels and the spiritual Internet forum the Nest of Angels as the carriers and legitimisers of the values of new spirituality}

\author{
Marko Uibu
}

Keywords: angels, new spirituality, online ethnography, religious syncretism, virtual community

The article observes angels as figures important for the contemporary spiritual milieu. The article focuses on an Estonian spiritual Internet forum, The Nest of Angels, and demonstrates how angels help to share virtual social support and create/confirm spiritual meanings. The forum, explicitly opposing the consumerist side of new spirituality, has become popular and demonstrates the nature and various roles of contemporary spiritual angels. Angels constitute a salient example of a recent religious change, becoming the symbols of human-centeredness and this-worldliness of modern religiosity. By asking why angels and why in the internet environment, the study identifies two main modes in which the Nest and the presence of angels have found their place in people's lives. Firstly, emotional support is shared, either by fellow users directly or by confirmations that angels will definitely help. Secondly, the Nest allows people to acquire knowledge both on spiritual and practical issues. As the Nest is dialogical, users can pose questions and find confirmations for their otherwise deviant experiences. Discussions in the Nest encourage everybody to interpret some situations and objects (like feathers) as signs from angels. This interpreting process might change people's perceptions of the world by adding a layer of positive emotions. The study demonstrates how the angelic presence (or at least endeavour towards the presence) helps to establish and keep the tonality of benevolence, which functions as the cornerstone of this virtual space. The ideology of the Nest and the community interactions support "connected knowledge": being empathic, intuitive, and individualistic. As a rule, commenters do not aim to challenge diverging views (common elsewhere in Internet communication), but attempt to understand and support each other. The trustful virtual relationships actualise the influence and the authority of people similar to users themselves, and increase distrust towards traditional authorities, especially those that do not accept people's free choice and subjectivism. Therefore, although quite opposite to a feminist empowerment ideology, new spirituality and angels support a subjective feeling of self-confidence that is framed with 'feminine' softness. In addition to active moderation and the strongly perceived normativity of keeping the place "high-vibrational", the angels themselves are guardians and guarantors of this intimacy, so knowledge and emotional support can be shared. The angels' divine nature supports people directly, but more importantly, makes them speak in a language of goodness and guarantees that fellow users, although not real angels, are trying to be at least slightly angel-like. Angels as symbolic figures unite power and benevolence; they legitimise values and epistemological positions characteristic to the milieu of new spirituality. 